\title{
Study on the Effects of Extreme Precipitation for Seven Growth Stages of Winter Wheat in Northern Weihe Loess Plateau, China
}

\author{
Ouk Sereyrorth ${ }^{1,2}$, Baowen Yan ${ }^{1 *}$, Khem Chunpanha1,2, Porn Lybun ${ }^{1,2}$, Pich Linvolak ${ }^{1,2}$ \\ ${ }^{1}$ College of Water Resources and Architectural Engineering, Northwest A\&F University, Xianyang, China \\ ${ }^{2}$ Faculty of Hydrology and Water Resources Engineering, Institute of Technology of Cambodia, Phnompenh, Cambodia \\ Email: ouk_sereyrorth@yahoo.com, *yanbaowen@nwsuaf.edu.cn
}

How to cite this paper: Sereyrorth, O., Yan, B.W., Chunpanha, K., Lybun, P. and Linvolak, P. (2020) Study on the Effects of Extreme Precipitation for Seven Growth Stages of Winter Wheat in Northern Weihe Loess Plateau, China. Journal of Water Resource and Protection, 12, 358-380. https://doi.org/10.4236/jwarp.2020.124021

Received: February 29, 2020

Accepted: April 18, 2020

Published: April 21, 2020

Copyright $\odot 2020$ by author(s) and Scientific Research Publishing Inc. This work is licensed under the Creative Commons Attribution International License (CC BY 4.0).

http://creativecommons.org/licenses/by/4.0/

(c) (i) Open Access

\begin{abstract}
The research on the characteristic frequency of precipitation is a great significance for guiding regional agricultural planning, water conservancy project designs, and drought and flood control. Droughts and floods occurred in northern Weihe Loess Plateau, affecting growing and yield of winter wheat in the area. Based on the daily precipitation data of 29 meteorological stations from 1981 to 2012, this study is to address the analysis of three different frequencies of annual precipitation at $5 \%, 50 \%$, and $95 \%$, and to determine the amount of rainfall excess and water shortage during seven growth stages of winter wheat at $5 \%, 10 \%$, and $20 \%$ frequencies, respectively. Pearson type III curve was selected for this study to analyze the distribution frequency of annual rainfall and rainfall amount following seven growth stages of winter wheat crop in 29 stations of Northern Weihe loess plateau. As a result of our study, annual precipitation is gradually increasing from southwest to northeast of Northern Weihe loess plateau. The highest amount of annual precipitation occurred in the Baoji area and the lowest precipitation covered by the northwest area of Northern Weihe loess plateau. Moreover, the amount of rainfall of seven growth stages indicates that excessive rainfall occurs not only in the first stage (sowing to tillering) and seventh stage (flowering to ripening) but also in second stage (tillering to wintering). In the seventh stage, a large amount of excessive rainfall occurred in Changwu, Bin, Qianyang, Fengxiang, Baojiqu, and Baojixian. Moreover, water shortage is distributed in the third stage (from wintering to greening), the fourth stage (from greening to jointing), the fifth stage (from jointing to heading), and the sixth stage (from heading to flowering). Furthermore, the worst water shortages occurred in Hancheng, Heyang, Chengcheng, Pucheng, Dali, Tongchuan, and Fuping in the fourth stage (greening to jointing stage). Even though we study
\end{abstract}


the crop water requirement under extreme rainfall conditions, the amount of rainwater still supply inadequate in some parts of the winter wheat growth stage. Therefore, this study provides main clues for the next step to study the irrigation water needs of winter wheat crops and to reduce agricultural risks in 29 counties in the northern loess plateau and other regions.

\section{Keywords}

Extreme Precipitation, Annual Precipitation, Seven Growth Stages, Winter Wheat Crop, Rainfall Excess, Water Shortage, Northern Weihe Loess Plateau

\section{Introduction}

Drizzle, rain, sleet, snow, graupel, and hail are the main forms of precipitation in the meteorological field [1]. Precipitation is a major component of the hydrological process and its variabilities are associated with drought, flood, and crop studies [2]. The study of the frequency precipitation characteristics is a great significance for guiding regional agricultural planning, agricultural water conservancy project designs and improving the risk aversion ability of agricultural drought and flood conditions [3]. Several researches performed a series of frequency precipitation pattern analysis; likewise Roy et al. [4] generated annual time series of seven different indices of extreme precipitation events, including total precipitation, largest 1,5 , and 30 day totals, and the number of daily events above the amount that marks the 90th, 95th, and 97.5th percentiles of all precipitation at each station in India; Zhang et al. [5] studied the changes of extreme precipitation in Canada, that provide a framework for mapping extreme events and characterize the spatial and temporal variation of extreme snowfall and rainfall events, Brunetti et al. [6] aim to study the trend of precipitation all over Italy by using Italian new datasets of daily precipitation(1951-1996); Feng et al. [7] analyzed the variation of spatial-temporal pattern of precipitation over China in the last 33 years (1980 to 2012) with resulting of upward annual precipitation trends; Guo et al. [8] studied on spatiotemporal patterns of Rainy-Season precipitation in Waihe river basin; and Li et al. [9] analyzed the frequency of precipitation extreme events in Heihe river basin. Fang et al. [10] observed changes of the regional extreme precipitation pattern events through the analysis of observed daily data in China; Wang et al. [11] extended that the previous analysis of extreme precipitation trends, especially the trends from 1961 to 2001; Zhai et al. [12] Studied on trends in annual and seasonal total precipitation in extreme daily precipitation, which resulted in that annual total precipitation has significantly decreased over southern northeast China. According to previous study, many researchers applied the various probability functions to analyze the distribution frequency and some authors evaluated its performance by determining the best fitting results. From Olofintoye et al. [13] compared the performance of probability function distribution; the result showed that the Pearson type III gives 
the best performance for peak daily rainfall distribution. Sheng et al. [14] also compared the efficiency of probability function for annual, seasonal, and monthly rainfall in Japan. The Pearson type III distribution shows the best fit to observe monthly rainfall and spring precipitation and performed very well for short time scale [15]. In recent publication, [16] Parvez et al. applied Pearson type III to estimate short duration rainfall to obtain the maximum depth and intensity for various short durations of each station. From Singh et al. [17], stated that Pearson type III distribution is the generalized gamma distribution and is one of the most popular distributions for hydrologic frequency analysis such as flood frequency analysis, hourly, monthly and annual precipitation frequency etc.

Plenty of Chinese scholars involved flood and drought in Northern Weihe loess plateau, Shaanxi. The occurrence of drought and flood is between the 8th and the 13th in [18]. Yin et al. [19] showed that the differences in natural disasters, such as high occurring frequencies of drought, flood and waterlog disasters, occurred synchronously. The analyzed results of historical data also revealed that, before the Ming Dynasty and Qing Dynasty, the drought, flood and waterlog disasters occurred frequently when the capital city was constructed in northern Weihe loess plateau; otherwise, the occurring frequencies of these natural disasters were significantly reduced. Wu et al. [20] determined the extreme value of annual seasonal precipitation trends and analyzed the influence of drought and flood events in the Wei river basin, Shannxi, with the result of a downward trend in the Wei river basin. Therefore, Northern Weihe Loess Plateau of Shaanxi province is selected for this study. Relevance of the previous studies on the impact of flood and drought on agriculture production has mainly focused on quantifying the relationship between the frequency and intensity of drought, flood, and disaster-affected damaged croplands [21]. Due to Chinese book [22], winter wheat crop is major crop productivity, grain yield about $1500 \mathrm{~kg} / \mathrm{hm}^{2}$, in Shaanxi. It is not only the main crop in China in which fulfills the demand for $1 / 3$ Chinese population [23] but also a vital output for the world, with an annual output of 582.7 million tons. The improvement of the effective utilization of precipitation resources on winter wheat crop is strongly concerned. Relevant studies on winter wheat [24], winter wheat evapotranspiration was estimated under drought stress during several growth stages and Yu et al. [25] studied the impact of droughts on winter wheat yield in different growth stages. Hong et al. [26] determined the amount of water deficit of winter wheat in the different growth stages. Zhenwei et al. [27] analyzed crop water requirement and the deficit of winter wheat crop, Zhihong et al. [28] and Ting et al. [29] studied on rainfall sensitivity on the yield of winter wheat in different growth stages. Sun et al. [30] analyzed the spatial distribution characteristics of precipitationin the whole growing period of winter wheat crops. Although the many previous pieces of research have studied rainfalls related to irrigation, they still lack the crucial point, extreme rainfall frequency, which is sensitive to yield production.

Therefore, this paper aims to study about analysis of the three different frequencies of annual precipitation at $5 \%, 50 \%$ and $95 \%$, and determination of 
rainfall excess amount and water shortage of winter wheat in seven growth stages frequency $5 \%, 10 \%$, and $20 \%$ of 29 counties in Northern Weihe loess plateau.

\section{Materials and Methods}

\subsection{Materials}

\subsubsection{Research Area}

Northern Weihe loess plateau is one of the regions in Shaanxi province of China and covered approximately 55,500 square kilometers; it shares a border with the Baoji to the west, Tongguan to the east, Qinling mountain to the south and the North Mountain to the north. The main landform is the Weihe Plain and its river terraces covered by loess. The area has been boasted as "Qinchuan with a length of 400 kilometers which covers Xian, Baoji, Xianyang, Weinan, Tongchuan and Yangling districts. It is located between $103^{\circ}-110^{\circ} \mathrm{E}$ and $34^{\circ}-38^{\circ} \mathrm{N}$ with the average elevation of 520 meters. The climate condition in the area is seasonally temperate a semi-humid monsoon with $13.3^{\circ} \mathrm{C}$ annual average temperature and annual mean precipitation between 500 to 650 millimeters. The terrain is higher in the southern and northern areas, and lower in the central and eastern areas. The research classifies the Northern Weihe loess plateau into two regions as the maps are presented in Figure 1.

\subsubsection{Data Collection}

1) Precipitation data

All daily precipitation data are presented by the department of the hydrology of Shaanxi province. All boundary data of China were downloaded from Global Administrative Areas (https://www.gadm.org/).

List of all 29 stations of precipitation data from1981 to 2012 in each county of Nothern Weihe losses plateau is given as Table 1.

2) Crop water needs of winter wheat in seven growth stages

Based on Chinese research from Xiao et al. [31], studied on relationship between winter wheat production with rainfall and compensation irrigation period

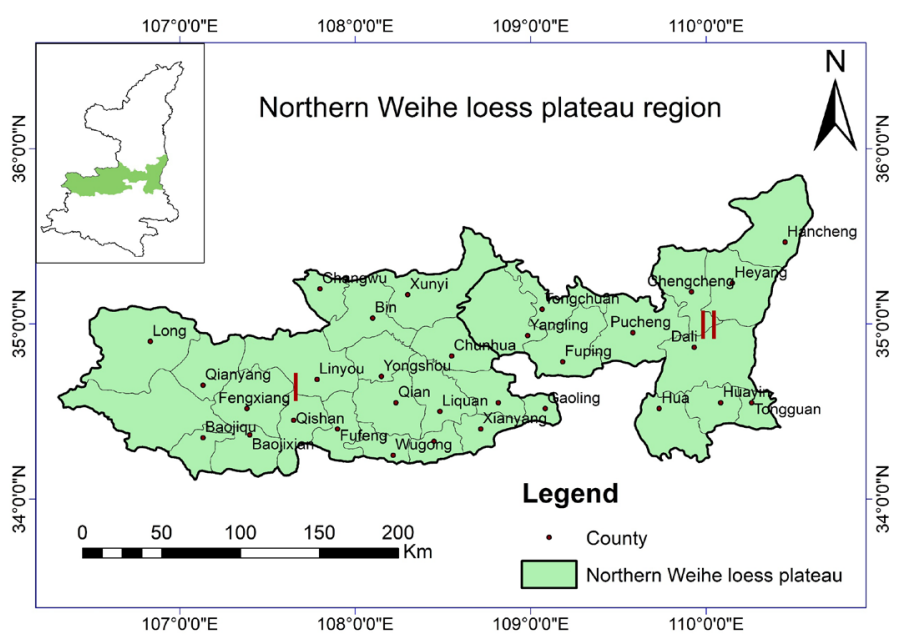

Figure 1. Location map of the study area. 
Table 1. List of all county in Northern Weihe losses plateau.

\begin{tabular}{|c|c|c|c|c|}
\hline Station ID & County & Longitude & Latitude & Elevation $(\mathrm{m})$ \\
\hline 57035 & Qian & $108^{\circ} 14^{\prime}$ & $34^{\circ} 33^{\prime}$ & 636.70 \\
\hline 57022 & Linyou & $107^{\circ} 47^{\prime}$ & $34^{\circ} 41^{\prime}$ & 1065.70 \\
\hline 57040 & Gaoling & $109^{\circ} 05^{\prime}$ & $34^{\circ} 31^{\prime}$ & 378.90 \\
\hline 53955 & Hancheng & $110^{\circ} 27^{\prime}$ & $35^{\circ} 28^{\prime}$ & 458.80 \\
\hline 57003 & Long & $106^{\circ} 50^{\prime}$ & $34^{\circ} 54^{\prime}$ & 925.10 \\
\hline 53929 & Changwu & $107^{\circ} 48^{\prime}$ & $35^{\circ} 12^{\prime}$ & 1206.80 \\
\hline 53947 & Tongchuan & $109^{\circ} 04^{\prime}$ & $35^{\circ} 05^{\prime}$ & 979.70 \\
\hline 53948 & Pucheng & $109^{\circ} 35^{\prime}$ & $34^{\circ} 57^{\prime}$ & 499.90 \\
\hline 57029 & Liquan & $108^{\circ} 29^{\prime}$ & $34^{\circ} 30^{\prime}$ & 544.40 \\
\hline 53949 & Chengcheng & $109^{\circ} 55^{\prime}$ & $35^{\circ} 11^{\prime}$ & 680.10 \\
\hline 57054 & Tongguan & $110^{\circ} 34^{\prime}$ & $34^{\circ} 33^{\prime}$ & 556.60 \\
\hline 57031 & Chunhua & $108^{\circ} 33^{\prime}$ & $34^{\circ} 49^{\prime}$ & 1013.50 \\
\hline 57030 & Yongshou & $108^{\circ} 09^{\prime}$ & $34^{\circ} 42^{\prime}$ & 998.70 \\
\hline 57034 & Wugong & $108^{\circ} 13^{\prime}$ & $34^{\circ} 15^{\prime}$ & 449.10 \\
\hline 57037 & Yangling & $108^{\circ} 59^{\prime}$ & $34^{\circ} 56^{\prime}$ & 720.60 \\
\hline 53938 & Xunyi & $108^{\circ} 18^{\prime}$ & $35^{\circ} 10^{\prime}$ & 1277.90 \\
\hline 57026 & Fufeng & $107^{\circ} 54^{\prime}$ & $34^{\circ} 24^{\prime}$ & 583.70 \\
\hline 57023 & Bin & $108^{\circ} 06^{\prime}$ & $35^{\circ} 02^{\prime}$ & 841.30 \\
\hline 57024 & Qishan & $107^{\circ} 39^{\prime}$ & $34^{\circ} 27^{\prime}$ & 671.10 \\
\hline 57042 & Fuping & $109^{\circ} 11^{\prime}$ & $34^{\circ} 47^{\prime}$ & 473.20 \\
\hline 57016 & Baojiqu & $107^{\circ} 08^{\prime}$ & $34^{\circ} 21^{\prime}$ & 610.30 \\
\hline 57020 & Baojixian & $107^{\circ} 24^{\prime}$ & $34^{\circ} 22^{\prime}$ & 563.70 \\
\hline 57043 & Dali & $109^{\circ} 56^{\prime}$ & $34^{\circ} 52^{\prime}$ & 368.90 \\
\hline 57048 & Xianyang & $108^{\circ} 43^{\prime}$ & $34^{\circ} 24^{\prime}$ & 472.80 \\
\hline 53950 & Heyang & $110^{\circ} 09^{\prime}$ & $35^{\circ} 14^{\prime}$ & 710.10 \\
\hline 57049 & Hua & $109^{\circ} 44^{\prime}$ & $34^{\circ} 31^{\prime}$ & 342.30 \\
\hline 57055 & Huayin & $110^{\circ} 05^{\prime}$ & $34^{\circ} 33^{\prime}$ & 352.30 \\
\hline 57021 & Qianyang & $107^{\circ} 08^{\prime}$ & $34^{\circ} 39^{\prime}$ & 746.40 \\
\hline 57025 & Fengxiang & $107^{\circ} 23^{\prime}$ & $34^{\circ} 31^{\prime}$ & 781.80 \\
\hline
\end{tabular}

in North Shaanxi and Weibei areas, the study has classified the crop water requirement into five different regions of North Shaanxi and Weibei areas. In this study, only two regions were extracted, as shown in Figure 1. Irrigation supply, precipitation, and groundwater replenishment are the major sources of crop water consumption. However, the groundwater recharge remained stable [22], the crop water need only depends on the amount of irrigation supply and precipitation. The crop water needs in Northern Weihe loess plateau area will be presented as Table 2. 
Table 2. Crop water needs of winter wheat in seven growth stages of two regions of Northern Weihe loess plateau in mm.

\begin{tabular}{|c|c|c|c|c|c|c|c|c|}
\hline \multicolumn{8}{|c|}{ Crop water needs of winter wheat in seven growth stages in $\mathrm{mm}$} & \multirow[b]{2}{*}{ Total } \\
\hline Stages & $\begin{array}{l}\text { I } \\
\text { Sowing to } \\
\text { tillering }\end{array}$ & $\begin{array}{c}\text { II } \\
\text { Tillering to } \\
\text { wintering }\end{array}$ & $\begin{array}{c}\text { III } \\
\text { Wintering to } \\
\text { Greening }\end{array}$ & $\begin{array}{c}\text { IV } \\
\text { Greening to } \\
\text { Jointing }\end{array}$ & $\begin{array}{c}\mathrm{V} \\
\text { Jointing to } \\
\text { heading }\end{array}$ & $\begin{array}{c}\text { VI } \\
\text { Heading to } \\
\text { flowering }\end{array}$ & $\begin{array}{l}\text { VII } \\
\text { Flowering to } \\
\text { ripening }\end{array}$ & \\
\hline $\begin{array}{l}\text { Planting } \\
\text { date }\end{array}$ & $\begin{array}{l}16 \text { October } \\
\text { to } 17 \text { November }\end{array}$ & $\begin{array}{l}18 \text { November } \\
\text { to } 19 \text { December }\end{array}$ & $\begin{array}{l}20 \text { December } \\
\text { to } 05 \text { March }\end{array}$ & $\begin{array}{l}06 \mathrm{March} \\
\text { to } 28 \mathrm{March}\end{array}$ & $\begin{array}{l}29 \text { March } \\
\text { to } 23 \text { April }\end{array}$ & $\begin{array}{l}24 \text { April } \\
\text { to } 16 \text { May }\end{array}$ & $\begin{array}{l}17 \text { May } \\
\text { to } 06 \text { June }\end{array}$ & 221 days \\
\hline Region I & 32.192 & 28.168 & 40.24 & 60.36 & 80.48 & 88.528 & 72.432 & $402.4 \mathrm{~mm}$ \\
\hline Region II & 38.408 & 33.607 & 48.01 & 72.015 & 96.02 & 105.622 & 86.418 & $480.1 \mathrm{~mm}$ \\
\hline
\end{tabular}

\subsection{Methodology}

\subsubsection{Person Type III Frequency Distribution}

By [32], Person type III was the empirical frequency computational method. It estimated a set of parameters as starting values, adjusted parameters by means of empirical judgment, and selected a frequency curve that closely matches empirical data. In addition, the optimizing curve-fitting method was the best statistical parameter method of frequency curve to solve matching empirical data under certain fitting rules (that is objective functions).

Person type III is selected for this study based on above reviews; therefore, it is a suitable frequency analysis method to apply for determination amount of rainfall following winter wheat growing gaps at extreme value condition. The optimization result of rainfall amount is the main clue to calculate rainfall excess. The annual precipitation at $5 \%, 50 \%$, and $95 \%$ were analyzed to investigate the precipitation characteristic at three different events rainfall condition like $5 \%$ as extreme event of precipitation during the rainy season, $50 \%$ as normal period, and $95 \%$ as a summer rainfall event. And amount of rainfall during seven growth stages of winter wheat in 29 counties of Northern Weihe loess plateau at three different frequencies extreme events $5 \%, 10 \%$, and $20 \%$ in sequence was designed.

Person type III method was conducted in this study to analyze the distribution frequency of precipitation at seven growth stages of winter wheat crop and annual rainfall value of 29 stations to obtain the optimum value based on goodness-fit indicator parameters $\bar{X}, C_{v}, C_{s}$ and each stage is carried out respect to Table 3.

Pearson-III function has been used in the curve fitting method. It is the probability density function and the formula can be given as below:

$$
f(x)=\frac{\beta^{\alpha}}{\Gamma(\alpha)}\left(x-a_{0}\right)^{\alpha-1} \mathrm{e}^{-\beta\left(x-a_{0}\right)}
$$

that $\Gamma(\alpha)$ is $\Gamma$ function; $\alpha, \beta$, $a_{0}$ were three parameters of the curve. Its formulas can be given as below:

$$
\alpha=\frac{4}{C_{s}^{2}}
$$


Table 3. Annual rainfall frequency of Baojiqu from 1981 to 2012.

\begin{tabular}{cccc}
\hline Frequency (\%) & Rainfall (mm) & Frequency (\%) & Rainfall (mm) \\
\hline 0.01 & 1437.15 & 50 & 639.12 \\
0.05 & 1318.12 & 60 & 602.79 \\
0.5 & 1136.12 & 70 & 566.21 \\
1 & 1077.5 & 80 & 526.35 \\
2 & 1015.66 & 90 & 476.12 \\
5 & 928.54 & 95 & 438.89 \\
10 & 856.34 & 98 & 416.68 \\
20 & 775.31 & 99 & 378.79 \\
30 & 721.13 & 99.9 & 325.23 \\
40 & 677.58 & 99.99 & 267.17 \\
\hline
\end{tabular}

$$
\begin{gathered}
\beta=\frac{2}{C_{v} C_{s} \bar{X}} \\
a_{0}=\frac{C_{s}-2 C_{v}}{C_{s}} \bar{X}
\end{gathered}
$$

Remark: In hydrology, both coefficients need to be greater than or equal to zero, a flow cannot be negative.

\subsubsection{Ordinary Kriging Interpolation Method (OK)}

The selection of the geostatistical methods of ordinary kriging (OK) is to address the problem of estimating the excess rainfall value in seven winter wheat crop growth stages in the northern Weihe loess plateau. Based on [33], the kriging method uses trends in the map to extrapolate of no data areas, sometimes resulting in a minimum and maximum $Z$ values in the grid that is beyond the values in the data file. This is acceptable in a structural or topographical map, but not in an isolines map where the extrapolation produces negative thickness values. Kriging method has varieties type of calculations. Among them, Ordinary kriging is the most widely used in the kriging method. It serves to estimate a value at a point of a region for which a variogram is known by using data in the neighborhood of the estimation location. Ordinary kriging can also be used to estimate a block value. With local second-order stationarity, ordinary kriging implicitly evaluates the mean in a moving neighborhood. To see this, first, a kriging estimation of the local means is set up; then a simple kriging estimator using this Kriged mean is examined. Ordinary kriging based on the concept of a basic linear regression algorithm. The estimation of the location of interests of value $x_{0}$ from the $n$ neighboring sample points of value $x_{\alpha}$ and combining them linearly with weights $x_{\alpha}$ can be given as:

$$
Z^{*}\left(x_{0}\right)=\sum_{\alpha=1}^{n} w_{\alpha} Z\left(x_{\alpha}\right)
$$

where: $Z\left(x_{\alpha}\right)$ is the random variable model at the location $x_{\alpha}$; 
$x_{\alpha}$ is n data locations;

$w_{\alpha}$ is the ordinary Kriging weight;

$Z^{*}\left(x_{0}\right)$ is the estimated value.

\section{Results}

\subsection{Annual Precipitation of Different Frequencies at 5\%, 50\%, and $95 \%$}

Figure 2 illustrates the spatial distribution of three different frequencies of annual precipitation in the Northern Weihe loess plateau from 1981 to 2012. A 5\% frequency of precipitation indicates the extreme value of precipitation during the rainy season. The extreme precipitation around $880 \mathrm{~mm}$ to $900 \mathrm{~mm}$ occurred in the Northwest area of Northern Weihe loess plateau with elevation from 563.70 $\mathrm{m}$ to $610.30 \mathrm{~m}$ (Table 1), Baoji region (Baojiqu \& Baojixian). Within elevation from $458.8 \mathrm{~m}$ to $710.1 \mathrm{~m}$, the northern part area, Hancheng, Heyang, Chengcheng, Pucheng, was covered by the lowest precipitation range around $780 \mathrm{~mm}$ to $800 \mathrm{~mm}$. $50 \%$ frequency of annual precipitation shows the annual average precipitation in the Northern Weihe loess plateau. The southwest-partannual average precipitation ranged between $600 \mathrm{~mm}$ to $620 \mathrm{~mm}$, the northeast part was around $500 \mathrm{~mm}$ and $520 \mathrm{~mm}$ and the middle part was around $540 \mathrm{~mm}$ to $560 \mathrm{~mm}$. For the dry season, northwest area within elevation from $368.9 \mathrm{~m}$ to $710.1 \mathrm{~m}$, Hancheng, Heyang, Chengcheng, Pucheng, Dali, and Fuping covered by $95 \%$ frequency of the annual precipitation, the lowest precipitation, around $335 \mathrm{~mm}$ to $350 \mathrm{~mm}$. And the highest precipitation ranges from $400 \mathrm{~mm}$ to 425 $\mathrm{mm}$ cover over the area with elevation from $563.70 \mathrm{~m}$ to $1206.8 \mathrm{~m}$ such as Changwu, Linyou, Qianyang, Qishan, and Baoji region (Baoji Qu and Baoji Xian).

\subsection{Excess Rainfall and Water Shortage of Seven Growth Stages at Different Frequencies}

In this case study, rainfall data were recorded from 1981 to 2012. The amount of excess rainfall and shortage of seven growth stages determined through subtraction between two datasets such as rainfall and crop water need in each stage. Planting time of winter wheat crop was conducted on 16 October 1981 as Table 2 mentioned. The amount of rainfall of each stage is followed by the scheduled planting crops. It started from 16 October 1981 to 30 May 1982 for a whole period and the other period was followed by the time duration. Since the winter wheat crop water needs of each county are different, it classifies into two regions.

\subsubsection{Excess Rainfall of Sowing to Tillering Stage}

Figure 3 presents the spatial distribution of three different frequencies of excessive rainfall during Sowing to the Tillering stage in Northern Weihe loess plateau. The highest excess rainfall of three differents 5\%, 10\%, and $20 \%$ frequencies, were occurred in similar regions such as Chunhua, Qian, Liquan, Xianyang, 


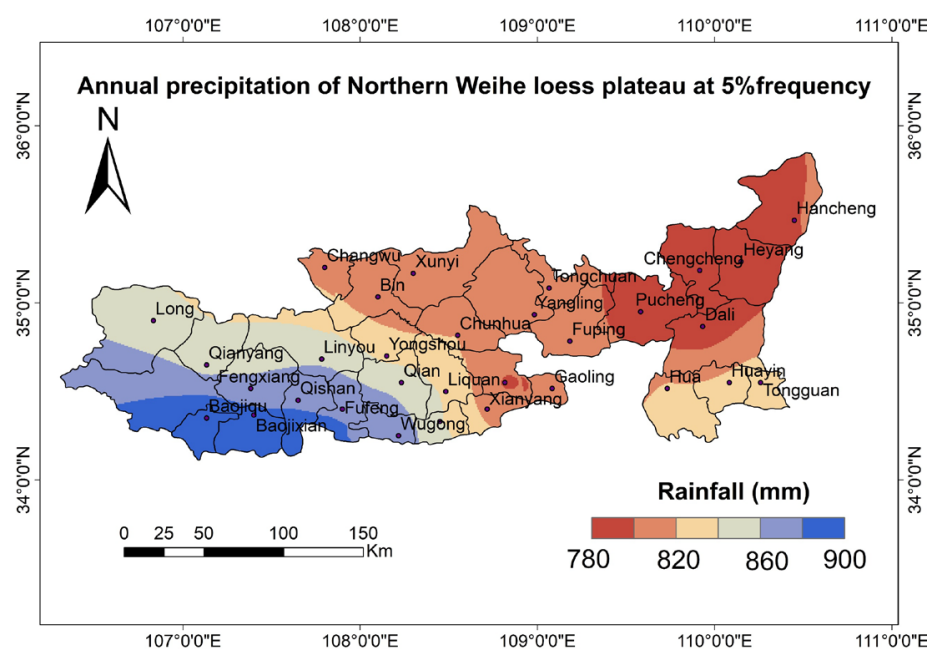

(a)

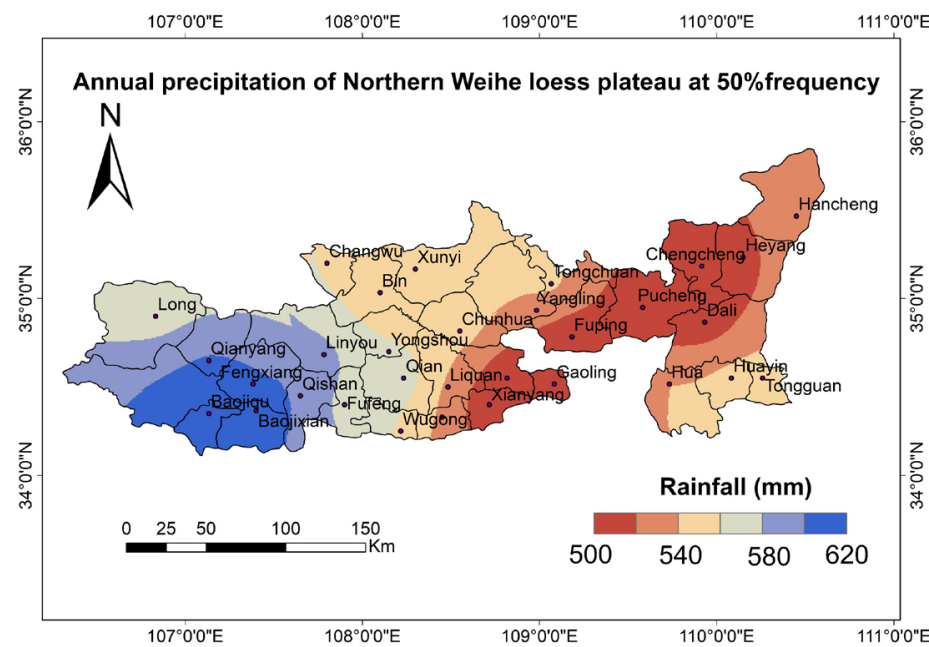

(b)

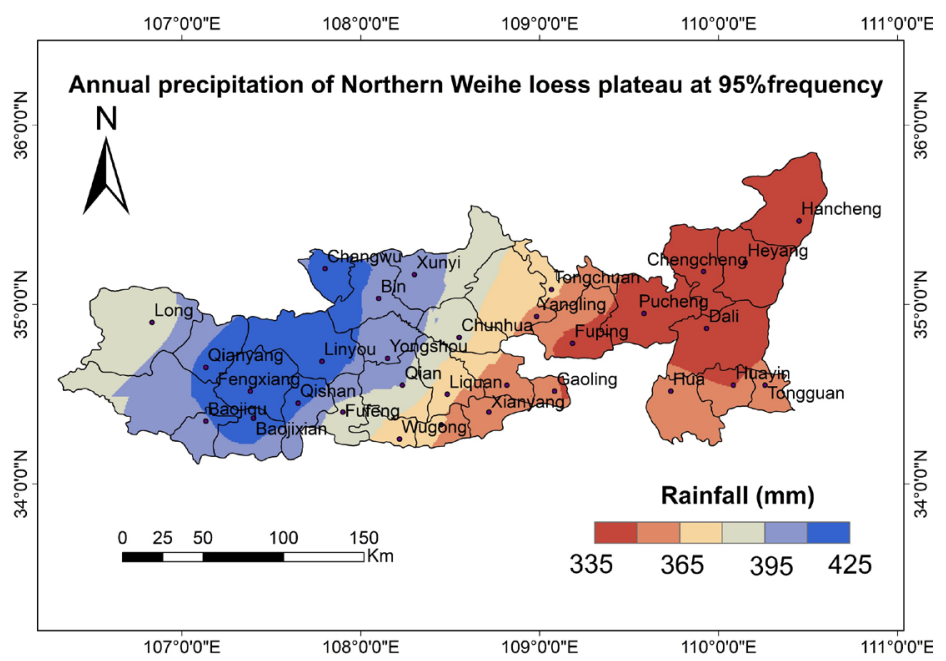

(c)

Figure 2. The spatial distribution of the different frequencies of annual precipitation in the Northern Weihe loess plateau, 1981-2012 (unit: $\mathrm{mm}$ ) ((a), (b) and (c) for 5\%, 50\%, $95 \%$, respectively). 


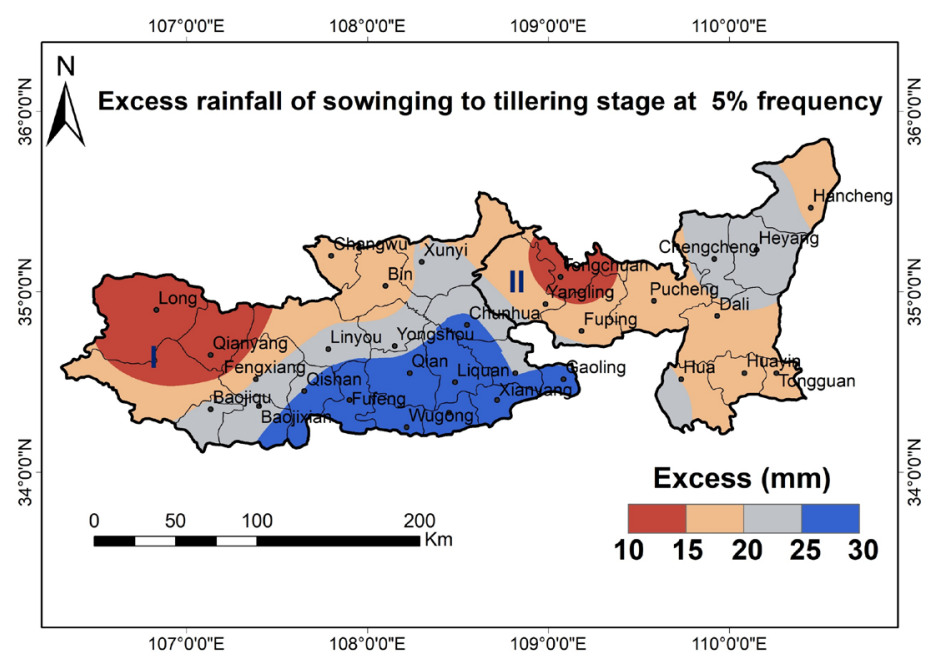

(a)

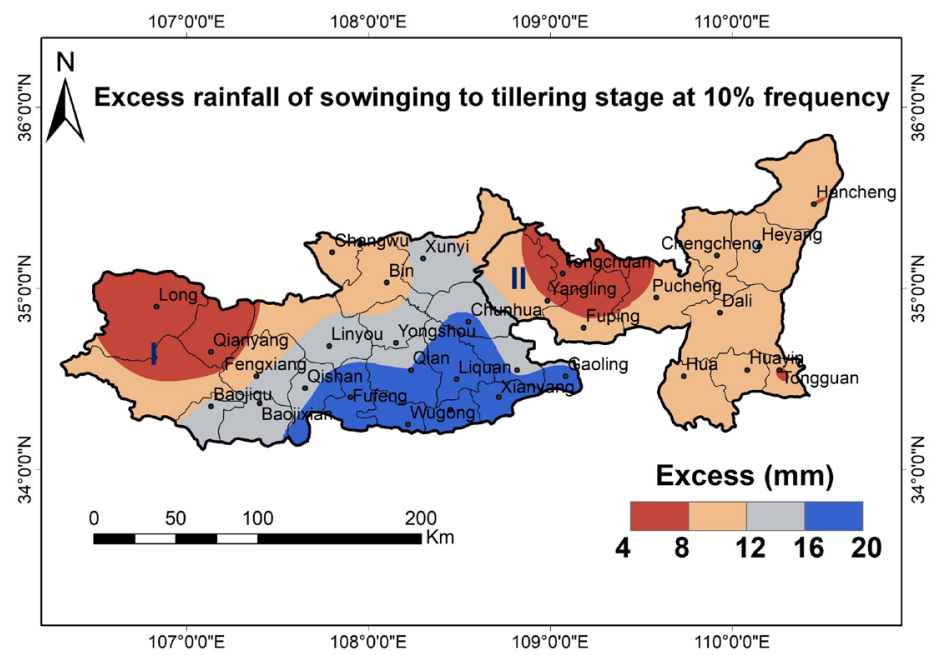

(b)

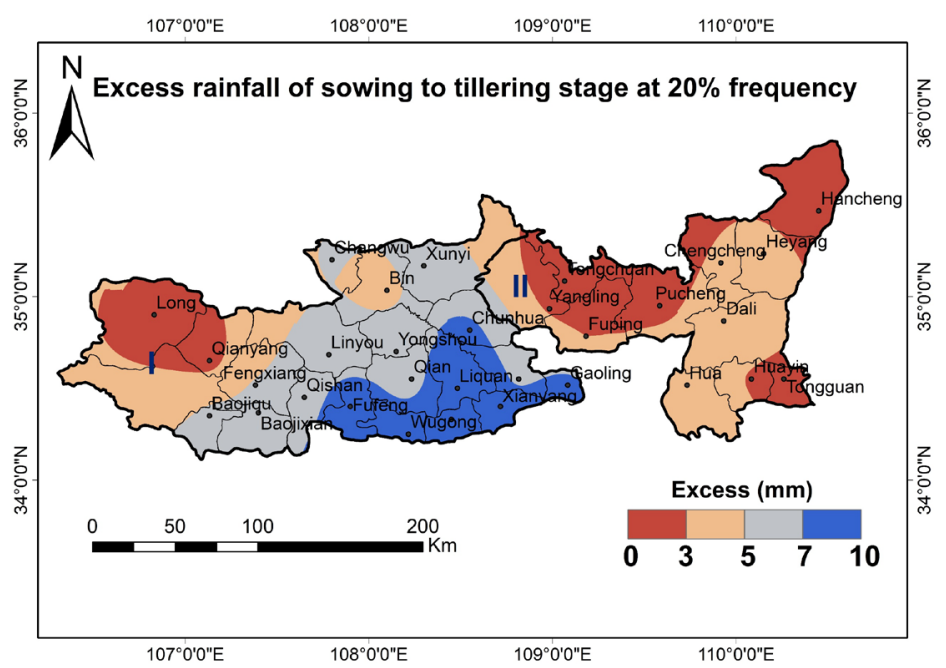

(c)

Figure 3. The spatial distribution of the different frequencies of excess rainfall of sowing to tillering stage in the Northern Weihe loess plateau (unit: $\mathrm{mm})((\mathrm{a}),(\mathrm{b})$ and (c) for $5 \%$, $10 \%, 20 \%$, respectively). 
Fufeng, and Wugong with the value ranged from 25 to $30 \mathrm{~mm}, 16$ to $20 \mathrm{~mm}$, and 7 to $11 \mathrm{~mm}$ respectively. However, the lowest condition of three different frequencies distributed in different areas. Long, Qianyang, Tongchuan, Yangling, Fuping with value ranges from 10 to $15 \mathrm{~mm}, 4$ to $8 \mathrm{~mm}, 0$ to $3 \mathrm{~mm}$ respectively except Hancheng, Huayin, and Tongguan were only covered by $20 \%$ condition with a value of 0 to $3 \mathrm{~mm}$. At $5 \%$ frequency, the amount of excess rainfall ranged between $15 \mathrm{~mm}$ to $20 \mathrm{~mm}$ covered by Changwu, Bin, Yangling, Fupinng, Pucheng, Dali, Huayin, Tongguan, and Hancheng. Moreover, Heyang, Chengcheng, Xunyi, Yongshou, Linyou, Baoji region (Baojiqu and Baojixian) with a value of between $20 \mathrm{~mm}$ and $25 \mathrm{~mm}$. Changwu, Bin, Fuping, Hancheng, Heyang, Chengcheng, Pucheng, Dali, Hua, Huayin, Tongguan account for the value range 8 to $12 \mathrm{~mm}$ of the $10 \%$ frequency excess rainfall. The value ranged between $12 \mathrm{~mm}$ and $16 \mathrm{~mm}$, covered by Xunyi, Linyou, Yongshou, Qishan, and Baoji region (Baojiqu and Baojixian). At 20\% frequency, the excess rainfall of Heyang, Chengcheng, Dali, Hua, and Fengxiang distributed within 0 to $4 \mathrm{~mm}$ and Xunyi, Changwu, Yongshou, Linyou, Qishan, and Baoji region was around $4 \mathrm{~mm}$ to 7 $\mathrm{mm}$.

\subsubsection{Excess Rainfall of Tillering to Wintering Stage}

Figure 4 shows the spatial distribution of three different frequencies of excessive rainfall during the tillering to wintering stage in Northern Weihe loess plateau. Based on observation, the excess rainfall of Changwu is the highest at $5 \%$ and $10 \%$ frequencies. Furthermore, Long, Qianyang, Fengxiang, Heyang, Changwu, Dali, and both Baoji regions consist of value within 0 to $10 \mathrm{~mm}$ and 0 to $1 \mathrm{~mm}$ for $5 \%, 10 \%$ frequencies, respectively $5 \%$ and $10 \%$ of rainfall excess of Xunyi, Bin, Linyou, Qishan, Fufeng, Wugong, Liquan, Qian, Yongshou, Chunhua, Tongchuan, Yangling, Fuping, Pucheng, Huayin, Tongguan, and Hancheng valued around 10 to $20 \mathrm{~mm}$ and 1 to $7 \mathrm{~mm}$. Xianyang, Gaoling, Wugong, and $\mathrm{Hu}-$ avaried from 20 to $30 \mathrm{~mm}$ and 7 to $13 \mathrm{~mm}$. However, amount of rainwater of $20 \%$ frequency supplied inadequate to winter wheat with the value from 1 to 13 $\mathrm{mm}$. In this case, water shortage appeared in Tillering to Wintering stage at $20 \%$ frequency.

\subsubsection{Water Shortage of Wintering to Greening Stage}

As shown, Figure 5 indicates the spatial distribution of three different frequencies of excess rainfall during Wintering to the Greening stage in Northern Weihe loess plateau. Since three different amounts of rainfall frequency distribution insufficiently supplied to winter wheat crops, the water shortage occurred in the Northern Weihe loess plateau. The serious water shortage existed in $20 \%$ frequency of amongst the counties of Northern Weihe loess plateau such as Hancheng, Heyang, Chengcheng, Tongchuan, Yangling, Pucheng, Dali, Fuping, Hua, Huayin, and Tongguan with values varied from 29 to $34 \mathrm{~mm}$. And, the least water shortage distributed in the central part of Northern Weihe loess plateau at $5 \%$ frequency within the amount of 7 to $11 \mathrm{~mm}$. At $10 \%$ frequency, the 


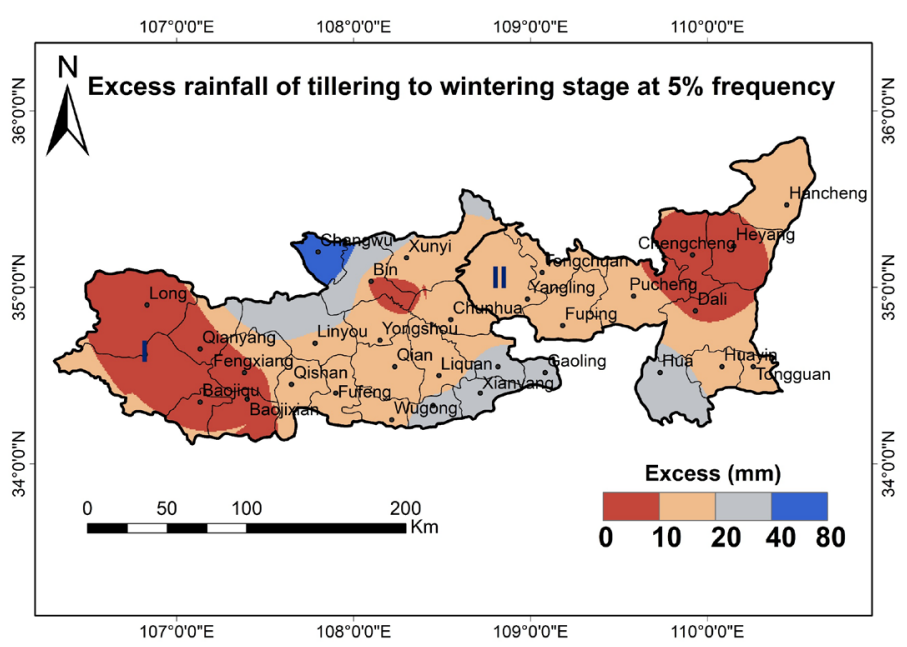

(a)

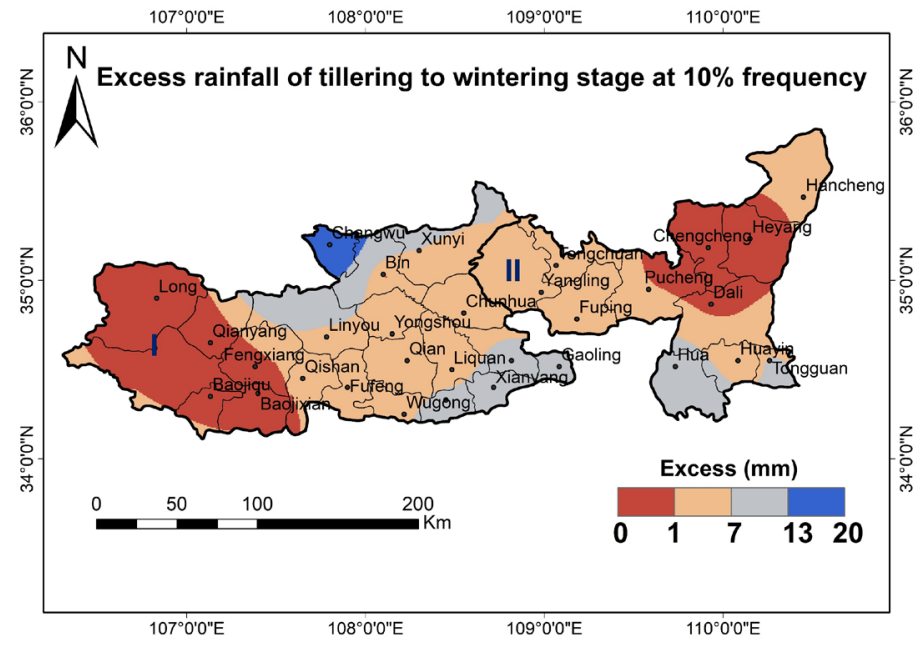

(b)

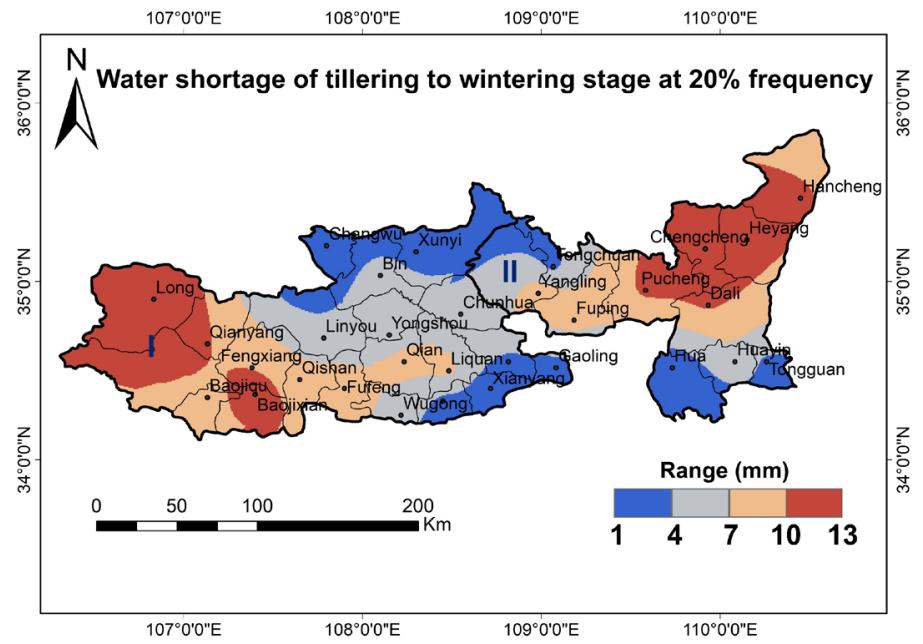

(c)

Figure 4. The spatial distribution of the different frequencies of excess rainfall of tillering to wintering stage in the Northern Weihe loess plateau (unit: $\mathrm{mm})((\mathrm{a}),(\mathrm{b})$ and (c) for $5 \%, 10 \%, 20 \%$, respectively). 


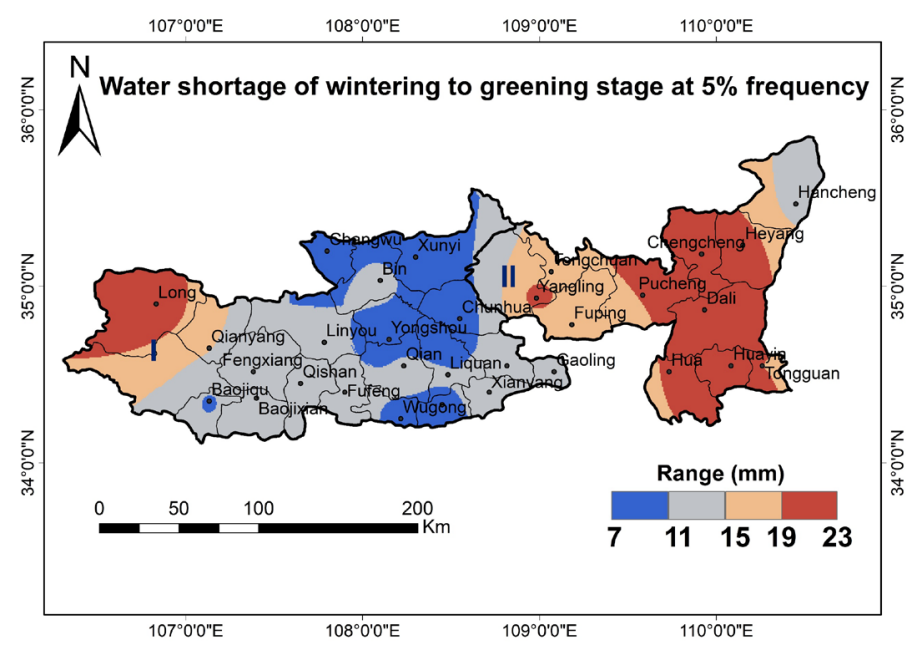

(a)

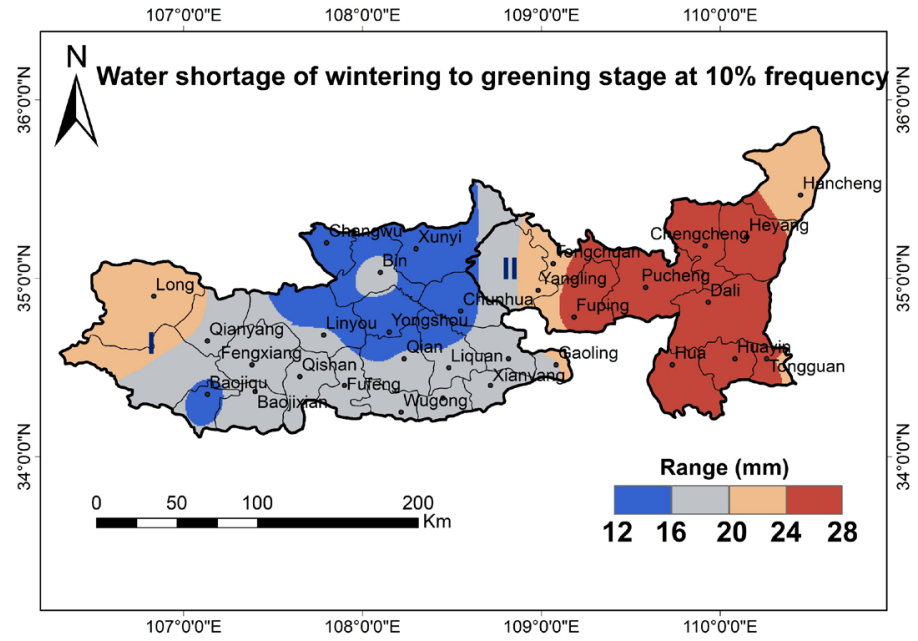

(b)

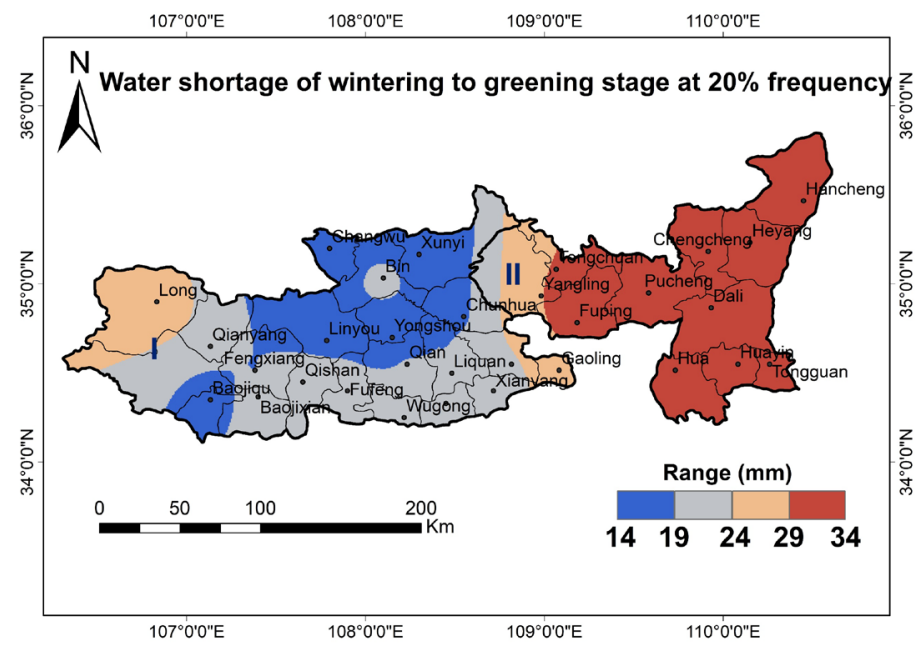

(c)

Figure 5. The spatial distribution of the different frequencies of excess rainfall of wintering to greening stage in the Northern Weihe loess plateau, (unit: $\mathrm{mm})((\mathrm{a}),(\mathrm{b})$ and (c) for $5 \%, 10 \%, 20 \%$, respectively). 
water shortage almost happened in a similar region as the $5 \%$ and $20 \%$ frequencies with value varied from 12 to $28 \mathrm{~mm}$.

\subsubsection{Water Shortage of Greening to Jointing Stage}

Figure 6 showed the spatial distribution of three different frequencies of water shortage during Greening to the Jointing stage in the Northern Weihe loess plateau. The result demonstrated that region II of Northern Weihe loess plateau suffered a water shortage. The largest amount of water shortage specifically is distributed in Hancheng, Heyang, Chengcheng, Tongchuan, Yangling, Fuping, Huayin, and Tongguan with about 55 to $60 \mathrm{~mm}$ at $20 \%$ frequency. And, another two various frequencies $5 \%$ and $10 \%$ also occurred the serious water shortage like $20 \%$ frequency with the value range between 45 to $50 \mathrm{~mm}$ and 50 to $55 \mathrm{~mm}$, respectively.

\subsubsection{Water Shortage of Jointing to Heading Stage}

Figure 7 presented the spatial distribution of three different frequencies of water shortage during jointing to the heading stage in Northern Weihe loess plateau. The largest amount of water shortage of three differents 5\%,10\%, and $20 \%$ frequencies occurred in similar regions II such as Heyang, Chengcheng, Tongchuan, Yangling, Pucheng, and Dali with the value ranged from 26 to $34 \mathrm{~mm}, 36$ to $44 \mathrm{~mm}$, and 45 to $52 \mathrm{~mm}$ respectively except Hancheng was only covered by $20 \%$ condition with a value of 45 to $52 \mathrm{~mm}$.

\subsubsection{Water Shortage of Heading to the Flowering Stage}

Figure 8 shows the spatial distribution of three different water shortage frequencies during heading to the flowering stage in Northern Weihe loess plateau. We observed that water shortage in region II is higher than the region I. The water shortage significantly increases from southwest to northeast with value varied from 30 to $90 \mathrm{~mm}$. Hancheng, Heyang, Pucheng, Tongchuan, Yangling, Pucheng, Huayin, and Tongguan highly occurred water shortage in region II at $20 \%, 10 \%$, and $5 \%$ frequencies which account for 80 to $90 \mathrm{~mm}, 70$ to $80 \mathrm{~mm}$, and 60 to $70 \mathrm{~mm}$, respectively. At $10 \%$ and $20 \%$ frequencies, Changwu, Xunyi, Bin, Chunhua, Linyou, Yangshuo, Qian, Liquan, Gaoling, and Xianyang also exist water shortage, in which the value was around 50 to $60 \mathrm{~mm}$, and60 to $70 \mathrm{~mm}$, respectively. Moreover, the amount of water shortage in Qianyang, Fengxiang, Qishan, Fuping, Wugong, Baojiqu, and Baojixian is around 40 to $50 \mathrm{~mm}$, and 50 to $60 \mathrm{~mm}$, respectively. At 5\% frequency, the water shortage of Qianyang, Fengxiang, Qishan, Baojiqu, and Baojixian is around 30 to $40 \mathrm{~mm}$. Similarly, at $5 \%$ frequency, the water shortage of Long, Changwu, Linyou, Fufeng, Wugong, and Qian region was about 40 to $50 \mathrm{~mm}$, Xunyi, Bin, Chunhua, Yongshou, Liquan, Xianyang, and Gaoling ranges between 50 to $60 \mathrm{~mm}$.

\subsubsection{Excess Rainfall of Flowering to Ripening Stage}

Figure 9 presents the spatial distribution of three different frequencies of excess rainfall during flowering to the ripening stage in the Northern Weihe loess plateau. 


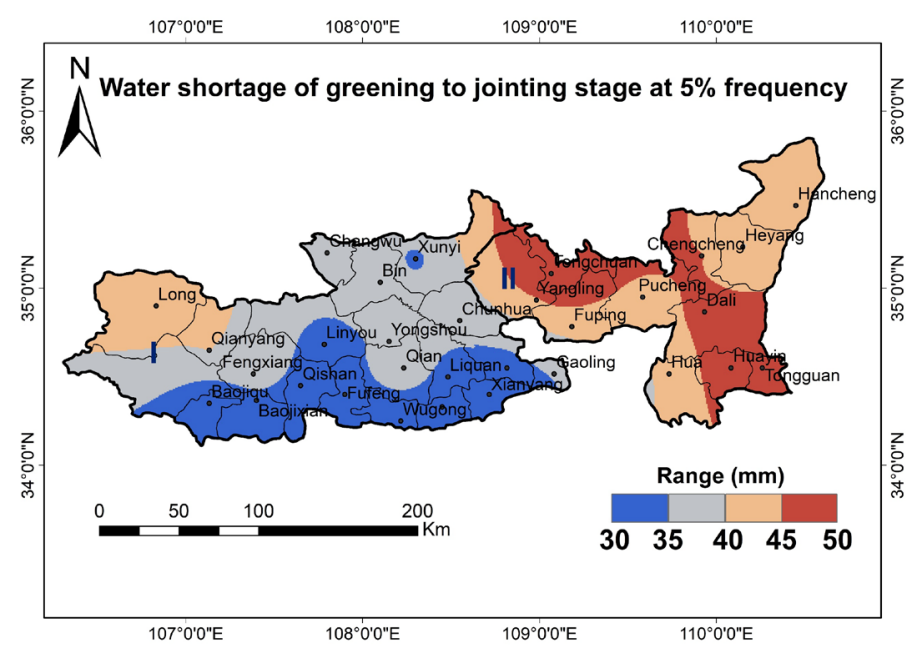

(a)

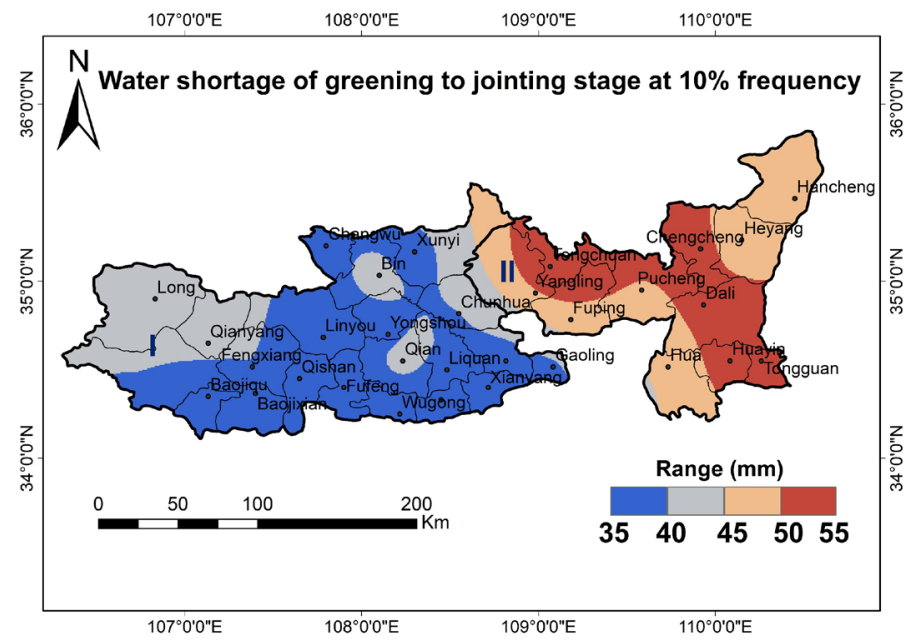

(b)

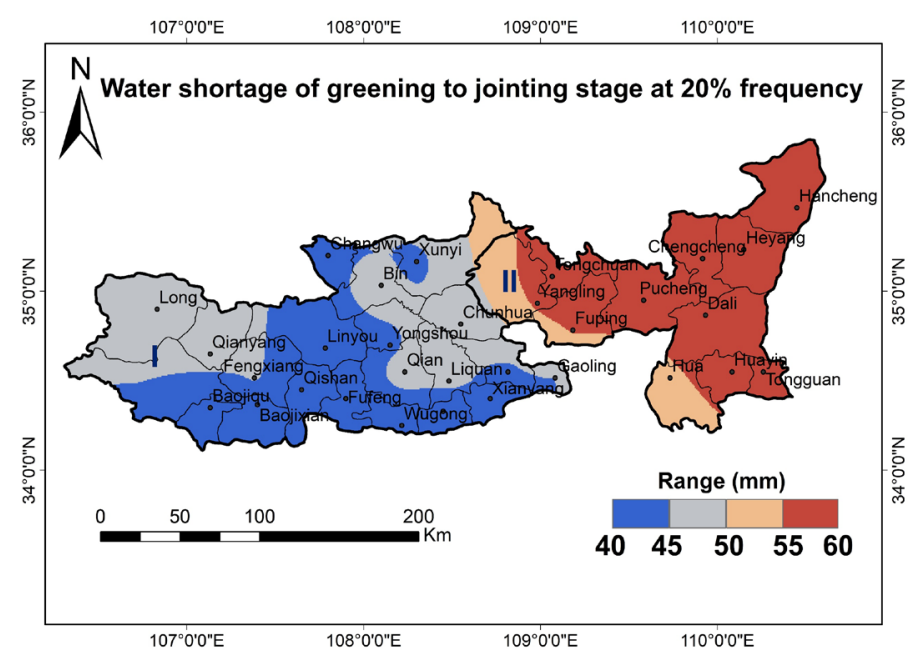

(c)

Figure 6. The spatial distribution of the different frequencies of excess rainfall of greening to the jointing stage in the Northern Weihe loess plateau (unit: $\mathrm{mm}$ ) ((a), (b) and (c) for $5 \%, 10 \%, 20 \%$, respectively). 


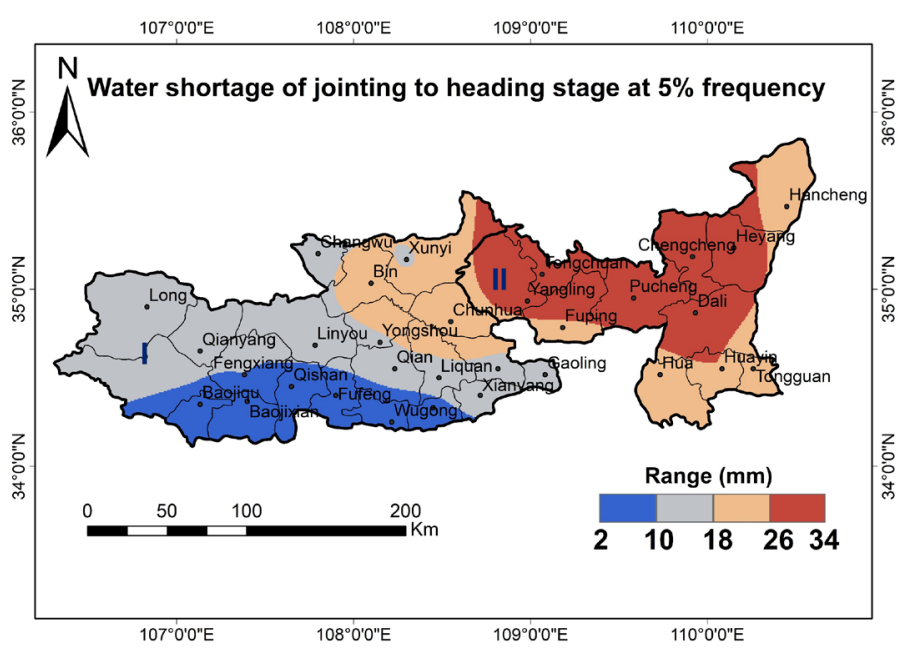

(a)

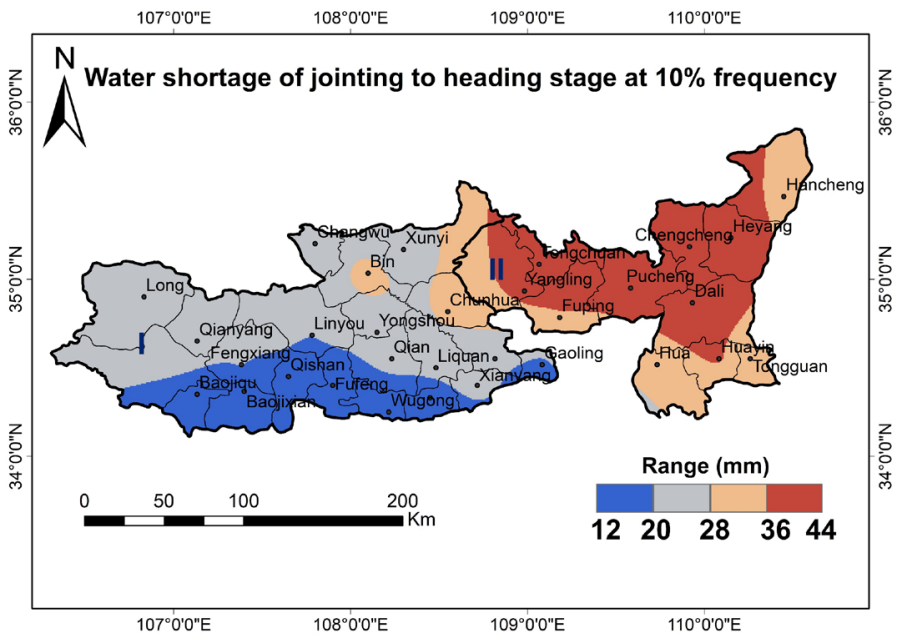

(b)

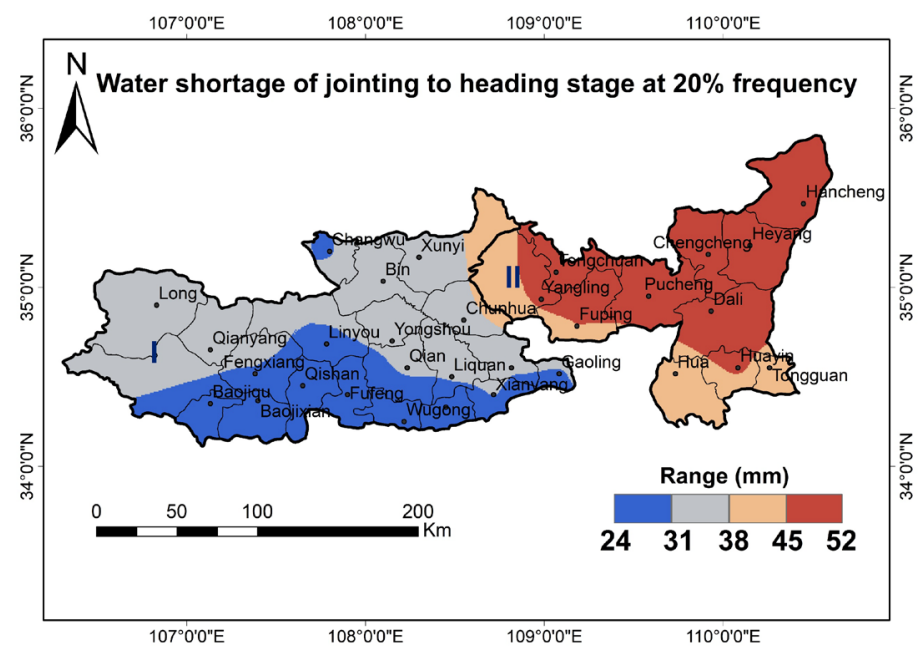

(c)

Figure 7. The spatial distribution of the different frequencies of excess rainfall of jointing to heading stage in the Northern Weihe loess plateau, (unit: $\mathrm{mm})((\mathrm{a}),(\mathrm{b})$ and (c) for $5 \%$, $10 \%, 20 \%$, respectively). 


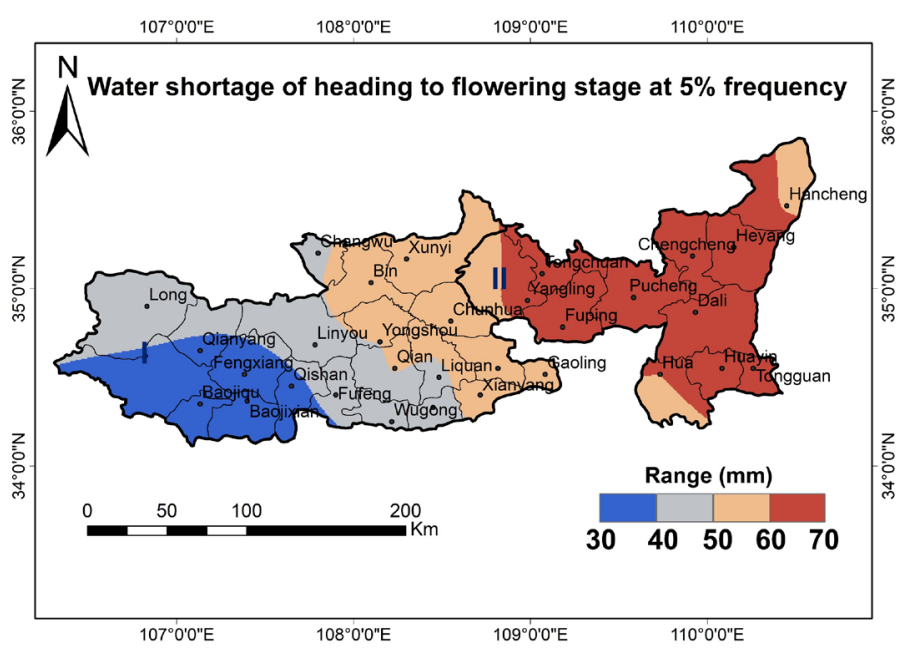

(a)

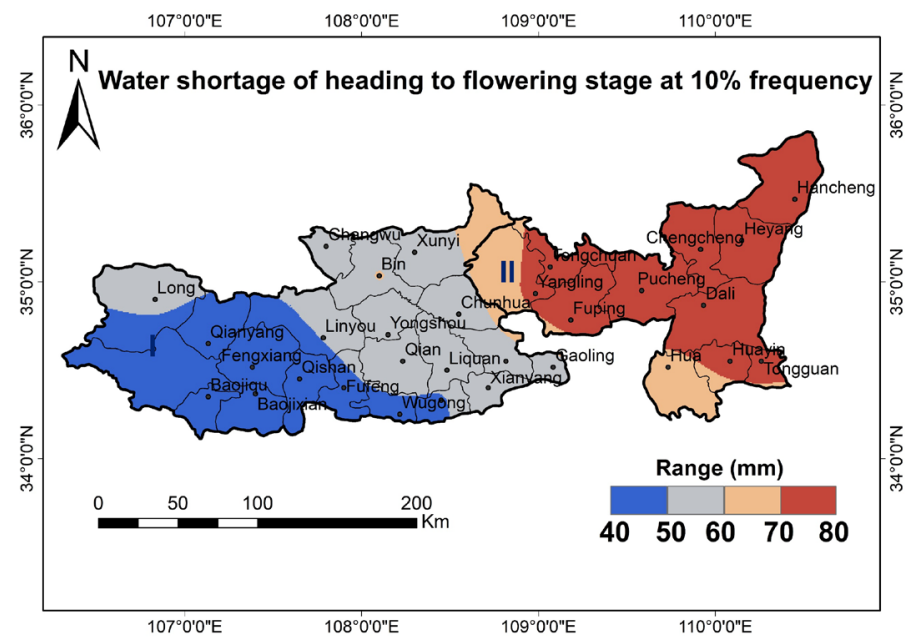

(b)

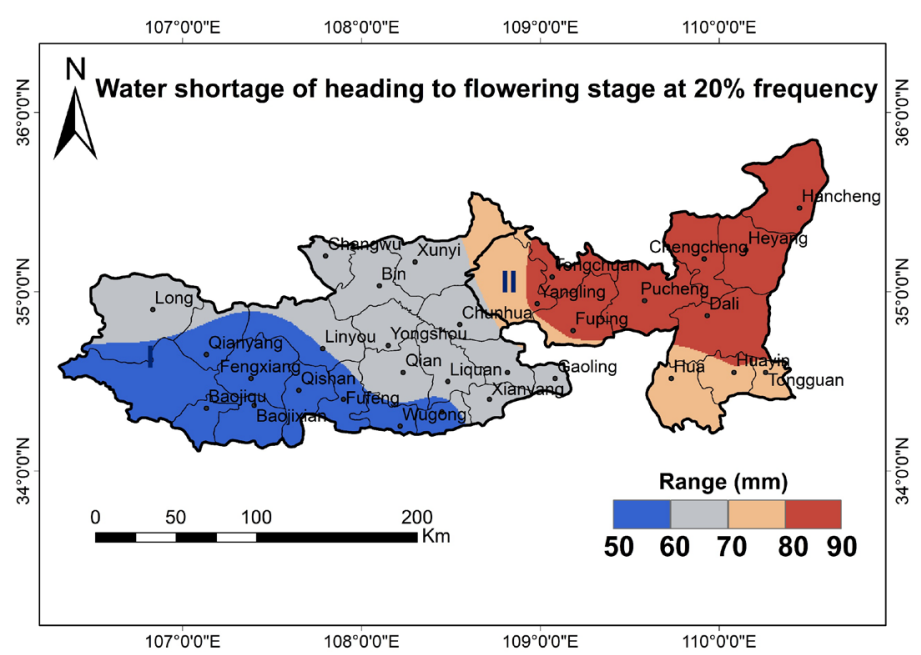

(c)

Figure 8. The spatial distribution of the different frequencies of excess rainfall of heading to flowering stage in the Northern Weihe loess plateau, (unit: $\mathrm{mm})((\mathrm{a}),(\mathrm{b})$ and (c) for $5 \%, 10 \%, 20 \%$, respectively). 


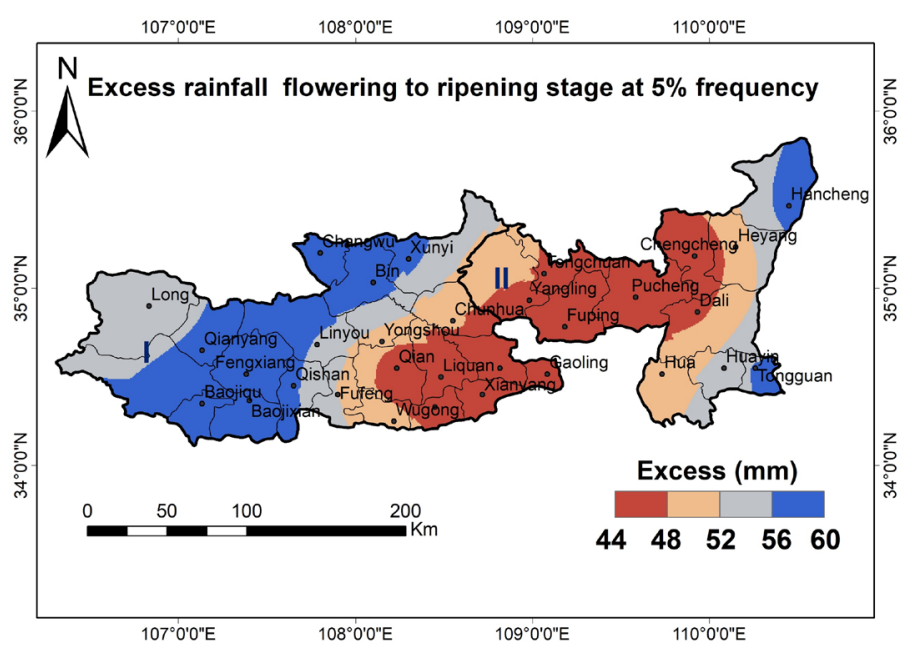

(a)

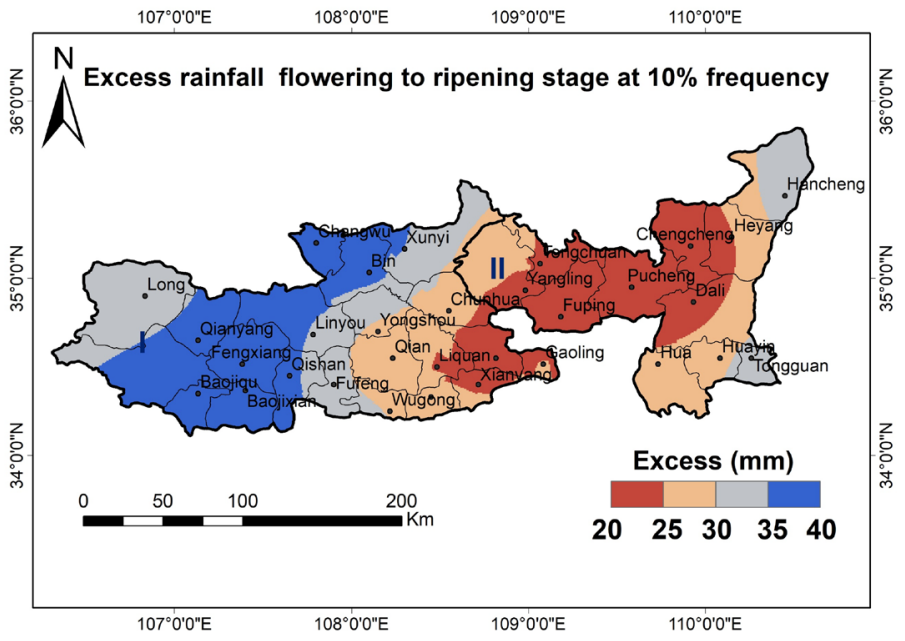

(b)

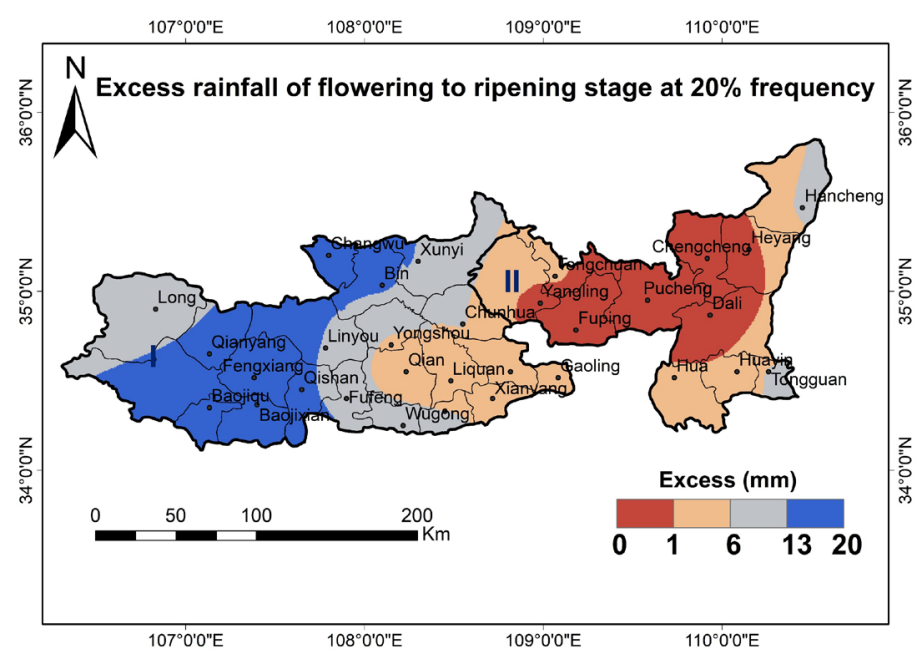

(c)

Figure 9. The spatial distribution of the different frequencies of excess rainfall of flowering to the ripening stage in the Northern Weihe loess plateau (unit: $\mathrm{mm}$ ) ((a), (b) and (c) for $5 \%, 10 \%, 20 \%$, respectively). 
The rainfall excess was classified into four categories. The blue color represents the largest amount of rainfall excess which was covered by the county in region I such as Changwu, Bin, Qianyang, Fengxiang, Baojiqu, Baojixian, and Qishan with value was around 56 to $60 \mathrm{~mm}, 35$ to $40 \mathrm{~mm}$, and 13 to $20 \mathrm{~mm}$ at $5 \%, 10 \%$, and 20\%, respectively. Chengcheng, Heyang, Pucheng, Dali, Tongchuan, Yangling and Fuping are fully sufficient for irrigation at $20 \%$ frequency during flowering to the ripening stage. At $10 \%$ and 5\% frequencies, Chengcheng, Heyang, Pucheng, Dali, Tongchuan, Yangling, Fuping, Qian, Liquan, Xianyang, and Wugong of rainwater exceed about 20 to $25 \mathrm{~mm}$, and 44 to $48 \mathrm{~mm}$, respectively. Hancheng, Tongguan, Xunyi, Yongshou, Linyou, Qishan, and Fufeng of 10\% and $20 \%$ frequencies with value were about 30 to $35 \mathrm{~mm}$ and 6 to $13 \mathrm{~mm}$.

\section{Discussion}

By using the Pearson-III probability function and ordinary kriging method, the spatial distribution characteristics of maps for annual precipitation at 5\%,50\%, and $95 \%$ were analyzed. And, the amount of rainfall during seven growth stages of winter wheat in 29 counties of Northern Weihe loess plateau at three different frequencies $5 \%, 10 \%$, and $20 \%$ in sequence was discussed. The result of annual rainfall was summarized in Figure 2; rainfall distribution from southeast to the northwest was decreased significantly like the previous study from Zhi et al. [34]. Notably, the result indicated the Baoji area was similar in the heaviest annual rainfall to the previous research [35] [36].

Under the same condition frequency $5 \%, 10 \%$, and $20 \%$ of precipitation of the whole growing period, the spatial distribution interpolation maps of rainwater excess and shortage at seven growth stages were analyzed. From Figure 3, the amount of rainwater was greater than crop water needs during the period of sowing to tillering stage (stage I) which was a negative influence on winter wheat crop growing. The amount of rainwater excess under $5 \%$ frequency was further beyond $10 \%$, and $20 \%$ frequency and it mostly impacts the part of the southwest area in the region II of Northern Weihe loess plateau. The rainwater excess also happened in Figure 4 stage II (tillering to wintering) at the 5\% and $10 \%$ frequency, in contrast, water shortage occurred at $20 \%$ frequency. From our findings, Table 2 represents that crop water needs significantly increased from stage III to VI and the amount of rainfall was lower during the period of each growth stage. Therefore, the water shortage occurred in stage III (wintering to greening) (Figure 5), IV (greening to jointing) (Figure 6), V (jointing to heading) (Figure 7), and VI (heading to flowering) (Figure 8) highly impacts on the winter wheat yields. Due to previous research from Li et al. [37] also explained that March precipitation was the main factor of stage IV of winter wheat; water was critical to winter wheat during this period, and its yield was decreased sharply if the water was insufficient. If the amount of precipitation was sufficient, the water supply could be accordingly increased to ensure crop yield. From Wang et al. [38] also mentioned about water shortage during stage IV, V, and VI and influence to winter wheat growth and yield formation. During a period of flowering 
to ripening (Figure 9), crop water needs of winter wheat remarkably decrease, rainfall excess existed at this stage. Even though we studied the crop water requirement under extreme rainfall conditions, the amount of rainwater still supplied inadequate in some parts of the winter wheat growth stage. Therefore, irrigation management should be designed to improve the crop yields of winter wheat.

\section{Conclusions}

Based on the daily precipitation data of 29 stations from 1981 to 2012, this paper analyses the spatial distribution of three different frequencies of annual precipitation at $5 \%, 50 \%$, and $95 \%$ and rainfall excess of seven growth stages of winter wheat crop at $5 \%, 10 \%$, and $20 \%$ in Northern Weihe loess plateau. The main conclusions were given as below:

1) A study of the distribution of annual precipitation in the Northern Weihe loess plateau shows that the lower of $5 \%$ frequency of annual rainfall gradually increases from the southwest to the northeast of Northern Weihe loess plateau. The highest annual rainfall occurred in the Baoji area and the lowest annual rainfall exists in Hancheng, Heyang, Chengcheng, Pucheng, and Dali. At 50\% frequency, the largest amount of annual rainfall also happened in Baoji area. And the minimum rainfall occurred in Chengcheng, Pucheng, Fuping, Gaoling, and Xianyang. At the high frequency of $95 \%$, the maximum annual rainfall was in Changwu, Qianyang, Fengxiang, Linyou, Baoji, and the minimum annual rainfall was in Hancheng, Heyang, Chengcheng, Pucheng, Dali, and Fuping. Normally, the water shortage happened in $95 \%$ frequency and the flood event occurred in $5 \%$ frequency.

2) The rainfall excess not only occurred in stage I (sowing to tillering) at 5\%, $10 \%$, and $20 \%$, but also happened in stage II (tillering to wintering) at 5\%, $10 \%$, and stage VII (flowering to ripening) at 5\%, 10\%, and 20\%. A large amount of rainfall excess exists in stage VII of $5 \%$ frequency and was covered by region I such as Changwu, Bin, Qianyang, Fengxiang, and Baoji region (Baojiqu and Baojixian). Since the rainwater was inadequate for the crop water balance of other growth stages, the water shortage is distributed in stage III (wintering to greening), stage IV (greening to jointing), stage V (jointing to heading), and stage VI (heading to flowering). Moreover, the serious water shortage occurred in Hancheng, Heyang, Chengcheng, Pucheng, Dali, Tongchuan, and Fuping at 20\% frequency of stage IV (greening to jointing stage). In conclusion, this research study may be useful for the next research for water requirement manipulation of winter wheat crops and reduce the rainfall-induced risk to agriculture in the climatically vulnerable of 29 counties of Northern Weihe loess plateau.

\section{Conflicts of Interest}

The authors declare no conflicts of interest regarding the publication of this paper. 


\section{References}

[1] Straka, J.M. (2009) Cloud and Precipitation Microphysics: Principles and Parameterizations. Cambridge University Press, Cambridge. https://doi.org/10.1017/CBO9780511581168

[2] Van Loon, A.F. and Laaha, G. (2015) Hydrological Drought Severity Explained by Climate and Catchment Characteristics. Journal of Hydrology, 526, 3-14.

https://doi.org/10.1016/j.jhydrol.2014.10.059

[3] Du, H., Xia, J. and Zeng, S. (2014) Regional Frequency Analysis of Extreme Precipitation and Its Spatio-Temporal Characteristics in the Huai River Basin, China. Natural Hazards, 70, 195-215. https://doi.org/10.1007/s11069-013-0808-6

[4] Roy, S.S. and Balling, R.C. (2004) Trends in Extreme Daily Precipitation Indices in India. International Journal of Climatology, 24, 457-466. https://doi.org/10.1002/joc.995

[5] Zhang, X., Hogg, W.D. and Mekis, E. (2001) Spatial and Temporal Characteristics of Heavy Precipitation Events over Canada. Journal of Climate, 14, 1923-1936. https://doi.org/10.1175/1520-0442(2001)014<1923:SATCOH >2.0.CO;2

[6] Brunetti, M., Colacino, M., Maugeri, M. and Nanni, T. (2001) Trends in the Daily Intensity of Precipitation in Italy from 1951 to 1996. International Journal of Climatology, 21, 299-316. https://doi.org/10.1002/joc.613

[7] Feng, Y. and Zhao, X. (2015) Changes in Spatiotemporal Pattern of Precipitation over China during 1980-2012. Environmental Earth Sciences, 73, 1649-1662. https://doi.org/10.1007/s12665-014-3517-x

[8] Guo, J., Ren, G., Xiong, M. and Huang, H. (2019) The Spatiotemporal Pattern of Rainy-Season Precipitation in the Haihe River Basin, North China. Hydrology, 6, 73. https://doi.org/10.3390/hydrology6030073

[9] Li, Z., Li, C., Xu, Z. and Zhou, X. (2014) Frequency Analysis of Precipitation Extremes in Heihe River Basin Based on Generalized Pareto Distribution. Stochastic Environmental Research and Risk Assessment, 28, 1709-1721. https://doi.org/10.1007/s00477-013-0828-5

[10] Fang, Z., Hang, D. and Xinyi, Z. (2010) Rainfall Regime in Three Gorges Area in China and the Control Factors. International Journal of Climatology, 30, 1396-1406. https://doi.org/10.1002/joc.1978

[11] Wang, Y. and Zhou, L. (2005) Observed Trends in Extreme Precipitation Events in China during 1961-2001 and The Associated Changes in Large-Scale Circulation. Geophysical Research Letters, 32, L09707. https://doi.org/10.1029/2005GL023769

[12] Zhai, P., Zhang, X., Wan, H. and Pan, X. (2005) Trends in Total Precipitation and Frequency of Daily Precipitation Extremes over China. Journal of Climate, 18, 1096-1108. https://doi.org/10.1175/JCLI-3318.1

[13] Olofintoye, O., Sule, B. and Salami, A. (2009) Best-Fit Probability Distribution Model for Peak Daily Rainfall of Selected Cities in Nigeria. New York Science Journal, 2, 1-12.

[14] Yue, S. and Hashino, M. (2007) Probability Distribution of Annual, Seasonal and Monthly Precipitation in Japan. Hydrological Sciences Journal, 52, 863-877. https://doi.org/10.1623/hysj.52.5.863

[15] Monish, N. and Rehana, S. (2020) Suitability of Distributions for Standard Precipitation and Evapotranspiration Index over Meteorologically Homogeneous Zones of India. Journal of Earth System Science, 129, 25. https://doi.org/10.1007/s12040-019-1271-x 
[16] Parvez, M.B. and Inayathulla, M. (2019) Assesment of the Intensity Duration Frequency Curves for Storms in Upper Cauvery Karnataka Based on Pearson Type III Extreme Value. World Academics Journal of Engineering Sciences, 6, 26-46.

[17] Singh, V.P. (1998) Log-Pearson Type III Distribution. In: Entropy-Based Parameter Estimation in Hydrology, Springer, Dordrecht, 252-274. https://doi.org/10.1007/978-94-017-1431-0_15

[18] Wen, X., Zhao, H. and Li, G. (2011) Drought/Flood Change in the Guanzhong Region between the 8 th and the 13 th Century. In: Proceedings of International Conference on Remote Sensing, Environment and Transportation Engineering, 1118-1121.

[19] Yin, S.Y., Huang, C.C., Qiu, L.H. and Jia, Y.F. (2007) Study on the Historical Drought and Flood Disasters in the Guanzhong Plain and the Urban Development. Arid Zone Research, 24, 77-82.

[20] Wu, H. and Qian, H. (2017) Innovative Trend Analysis of Annual and Seasonal Rainfall and Extreme Values in Shaanxi, China, Since the 1950s. International Journal of Climatology, 37, 2582-2592. https://doi.org/10.1002/joc.4866

[21] Zhang, Q., Li, Q., Singh, V.P., Shi, P., Huang, Q. and Sun, P. (2018) Nonparametric Integrated Agrometeorological Drought Monitoring: Model Development and Application. Journal of Geophysical Research: Atmospheres, 123, 73-88. https://doi.org/10.1002/2017JD027448

[22] An, W.S. and Wang, P. (1995) The Various Theories on Crop Cultivation.

[23] CropWatch (2014) Chapter 4. Crop and Growing Conditions in China. 68-77.

[24] Cui, Y., Jiang, S., Feng, P., Jin, J. and Yuan, H. (2018) Winter Wheat Evapotranspiration Estimation under Drought Stress during Several Growth Stages in Huaibei Plain, China. Water, 10, 1208. https://doi.org/10.3390/w10091208

[25] Yu, H., Zhang, Q., Sun, P. and Song, C. (2018) Impact of Droughts on Winter Wheat Yield in Different Growth Stages during 2001-2016 in Eastern China. International Journal of Disaster Risk Science, 9, 376-391. https://doi.org/10.1007/s13753-018-0187-4

[26] Hong, M.J.H.J.L. (1987) An Analysis of Major Crop Water Requirements and Supplies in Rainfed Agricultural Area in North China.

[27] Zhenwei, S., Hailin, Z., Jing, H. and Fu, C. (2009) Characters of Water Requirement for Main Crops and Field Water Balance in Beijing Region. Research of Agricultural Modernization, 30, 461-465.

[28] Zhihong, Z. (2008) Sensitivity Analysis of Rainfall in the Growth Stages on Yield of Winter Wheat. Journal of Anhui Agricultural Sciences, 36, 12134-12135.

[29] Dang, T.-H. and Gao, C.-Q. (2003) Study on Key Water Factors of Affecting Wheat Yield in Weibei Dry Highland. Research of Soil and Water Conservation, 10, 9-11.

[30] Sun, S., Yang, X., Li, K.N., Zhao, J., Ye, Q., Xie, W.J., Dong, C.Y. and Liu, H. (2005) Analysis of Spatial and Temporal Characteristics of Water Requirement of Winter Wheat in China. Transactions of The Chinese Society of Agricultural Engineering, 29, 72-82.

[31] Xiao, M.A., Kang, S., Zhao, Y., Kun, L.I. and Wang, F. (2000) Relationship between Winter Wheat Production with Rainfall and Compensation Irrigation Period in North Shaanxi and Weibei Areas. Journal of Northwest Agricultural University.

[32] Che, G.W. (2014) Pearson-III Frequency Curve Plotting in Excel Table. Applied Mechanics and Materials, 556-562, 5829-5834.

https://doi.org/10.4028/www.scientific.net/AMM.556-562.5829 
[33] Cressie, N. (1988) Spatial Prediction and Ordinary Kriging. Mathematical Geology, 20, 405-421. https://doi.org/10.1007/BF00892986

[34] Zhi, L. (2015) Trend and Abrupt Analysis of Rainfall Change During Last 50 Years in the WeiHe Basin. Earth Sciences, 4, 228-234.

https://doi.org/10.11648/j.earth.20150406.12

[35] Wen, L. (2013) Precipitation in the Weihe River Basin in Recent 60 Years. Arid Zone Research.

[36] Wang, S., Lei, X.H. and Zhang, F. (2013) Analysis on Variation Characteristics of Precipitation Time Series in Weihe River Basin during the Past 55 Years. Advanced Materials Research, 684, 246-252.

https://doi.org/10.4028/www.scientific.net/AMR.684.246

[37] Li, C., Zhang, H., Gong, X., Wei, X. and Yang, J. (2019) Precipitation Trends and Alteration in Wei River Basin: Implication for Water Resources Management in the Transitional Zone between Plain and Loess Plateau, China. Water, 11, 2407. https://doi.org/10.3390/w11112407

[38] Pengyun, W., Hui, W., Wanchun, L., Yan, Z. and Yan, T. (2009) Research on Water Demand and Water Shortage of Wheat Growing. Agricultural Meteorological Disaster Prevention and Mitigation and Food Security Branch of the 26th Annual Meeting of the Chinese Meteorological Society, 790-796. 